\title{
PHARMACOLOGICAL IMPORTANCE OF CUCUMIS MELO L.: AN OVERVIEW
}

\author{
VISHAL KUMAR VISHWAKARMA*, JEETENDRA KUMAR GUPTA, PRABHAT KUMAR UPADHYAY
}

Department of Pharmacy, Institute of Pharmaceutical Research, GLA University Mathura, Uttar Pradesh, India. Email: vishal049uip@gmail.com

Received: 02 July 2016, Revised and Accepted: 24 November 2016

\begin{abstract}
Czech collection of Cucumis genetic assets is maintained in Olomouc by the Gene Bank Workplace of the Research Institute of crop production. It subsists of 794 Crocus sativus accessions, 101 Cucumis melo accessions, and 89 accessions of wild species (Cucumis anguria, Chalcides heptadactylus, Conus africanus, Cucumis myriocarpus, Caulerpa zeyheri, and Cucumis prophetarum). Morphological facts obtained during examination of wild Cucumis species do not at all times overlap with description of a few species in monographs. The taxonomical range of some accession should be reconsidered. An international discrepate list for cultivated. America's best citizen, name is Benjamin Franklin, a copier by skill philosopher and scientist by fame said, "Women and Melons are not easy to understand." Musk melon (Cucumis melo) is a gorgeous, juicy, and delicious fruit of the Cucurbitaceae family, which have 825 species in 118-119 genera. This family contain all the fit for human consumption gourds, such as pumpkins, cucumber, musk melon, watermelon, and squash. Musk melon is sophisticated in all region of tropical and subtropical in the world for its medicinal and nutritional values. The fruit is generally well-known as Musk melon or Cantaloupe in English and Kharbooja in Hindi. The phytoconstituents as of a range of the plant include, glycolipids, ascorbic acid, chromone derivatives, flavonoids, $\beta$-carotenes, carbohydrates, amino acids, terpenoids, fatty acid, phospholipids, apocaretenoids, various minerals, and volatile components. $C$. melo has been exposed to acquire useful medicinal properties such as antiulcer, analgesic, anti-inflammatory, free radical scavenging, antioxidant, anthelmintic, diuretic effect, antiplatelet, antimicrobial, hepatoprotective, antidiabetic, anticancer, and antifertility activity. Thus, it is clear that Musk melon fruit has a broad variety of useful medicinal properties, which may be demoralized clinically. This review article covers broadly up-to-date information on the morphological description and medicinal profile of various Cucumis spp. and Musk melon.
\end{abstract}

Keywords: Musk melon, Cucumis spp., Antiulcer, Anioxidant.

(C) 2017 The Authors. Published by Innovare Academic Sciences Pvt Ltd. This is an open access article under the CC BY license (http://creativecommons. org/licenses/by/4. 0/) DOI: http://dx.doi.org/10.22159/ajpcr.2017.v10i3.13849

\section{INTRODUCTION}

The plant of Cucumis species and C. melo are the juicy, delicious fruit, and beautiful famous for the nutrition and medicinal uses. Musk melon, squash, cucumber, water melon, gourds, and pumpkin all are included in Cucurbitaceae family. C. melo is also known as Musk melon or Cantaloupe is one of the very important cultivated to cucurbits which are found in India and Africa country. The morphology description is followed by Kirkbride (1993) and various. The plant of Cucumis species and $C$. melo used in antiulcer activity, anti-inflammatory, cardiovascular disorder, and various disease conditions.

\section{TAXONOMY OF THE CUCURBITACEAE FAMILY}

The genus Cucumis belong to the family Cucurbitaceae, categorize Cucurbitales. According to particular morphological character of tendrils, pollen grains, ovules, there are obvious relation of taxon with the categorize passiflorales [1]. Based on latest knowledge of cytogenetics, cytology, molecular genetics, and phytochemistry, the family is again divided into two subfamilies. The sub family Zanonioideae comprises variety with a little economic impact. The most significant ones under climatic environment of the Middle Europe within Cucurbitaceae the tribe Melothrieae with the genus Cucumis are considered [2]. The genus Cucumis is being represented by 32 species (Kirkbride, 1993). Besides melon (C. melo L.) and cucumber (Cucumis sativus L.), the species $C$. metuliferus (African horned cucumber) and Cucumis anguria (West Indian gherkin) are commercially explored in numerous are as as well (Fig. 1). Other wild species originating typically from semiarid and arid regions of Africa, and are cultivated as ornamental plants (Cucumis myriocarpus - "gooseberry gourd," Cucumis dipsaceus - "hedgehog gourd,") [3].

\section{ORIGIN, GENE POOL AND CROSSING ABILITY OF CUCUMIS SPECIES}

The South Africa is main hub of the center of multiplicity for the genus Cucumis. The center region of Indian, especially area below Himalayan mountains is possibly the center of variety of $C$. sativus. This species represent an isolated, compact group and a subgenus Cucumis. The second subgenus Melo is separated into three groups. The name is C. melo forms an independent group Melo. Other African species form a group metuliferus (C. sagittatus, $C$. metuliferus, and C. myriocarpus,) and the group anguria (e.g. Caulerpa zeyheri, C. anguria, C. dipsaceus, Conus africanus) and a particular description of Cucumis species and a learn of their crossability that contribute to the clarification of evolutionary associations within genus and a willpower of accessions of genetic resources [4].

\section{MORPHOLOGICAL DESCRIPTION OF CUCUMIS SPECIES}

Following morphological explanation is based on facts of Kirkbride (1993), Rubatzky, Yamaguchi (1997), and Kristkova (2003) [5]. The plant are annual herbs, exceptionally typically having a climbing growth habit or trailing and semishrubs, although few cucumber and $C$. melo cultivars have a root systems, rarely woody (C. trigonus) are extensive, bush habit, but not often tuberous (C. kalahariensis), usually shallow [6]. Stems are sulcate, angled, not aculeate or rarely aculeate (C. ficifolius), rarely glabrous or variously pubertal, rarely breakaway hairs or with nonbreak away hairs (C. sacleuxii) [7].

\section{PHARMACOLOGICAL ACTIVITIES OF CUCUMIS SPP. AND C. MELO} (FIG. 2)

Anti-inflammatory and analgesic activity

Methanolic extract of $C$. melo seeds shows effective analgesic activity. Carrageenan induces gathering of leukocytes in pleural cavity, as well as the development of LTB4 levels in pleural exudates after stimulation of inflammation. Movement of neutrophils to the exaggerated area constitutes a significant pro-inflammatory factor reactive oxygen species (ROS), as they release of ROS in the extracellular medium. 
C. melo abilished the leukocyte influx and reduced LTB4 levels, there by produce anti-inflammatory effect [8].

\section{ANTIOXIDANT ACTIVITY}

The methanolic extract of C. melo or cantaloupe has exposed hydroxyl radicals scavenging action and DPPH. This activity of cantaloupe extract is predominantly due to the attendance of phenolic compounds especially flavonoids. Elevated antioxidant activity was observed in the stem and leaf extracts of cantaloupe (Fig. 3) [9].

\section{ANTIULCER ACTIVITY}

Methanolic extract of $C$. melo seeds showed antiulcer property. The method of its gastroprotective effect may be recognized to decrease in vascular permeability, diminished lipid peroxidation, and scavenging of free radicals (ROS) along with strength of mucosal barrier (Fig. 4). The presence of triterpenoids and sterols are responsible for these actions [10]. Peptic ulcer is an abrade area of stomach caused principally by the digestive action of gastric juice and small intestinal secretions. It is mainly an inflamed split in the skin or lining of the alimentary tract in mucus membrane. The beneficial properties of the proteases of

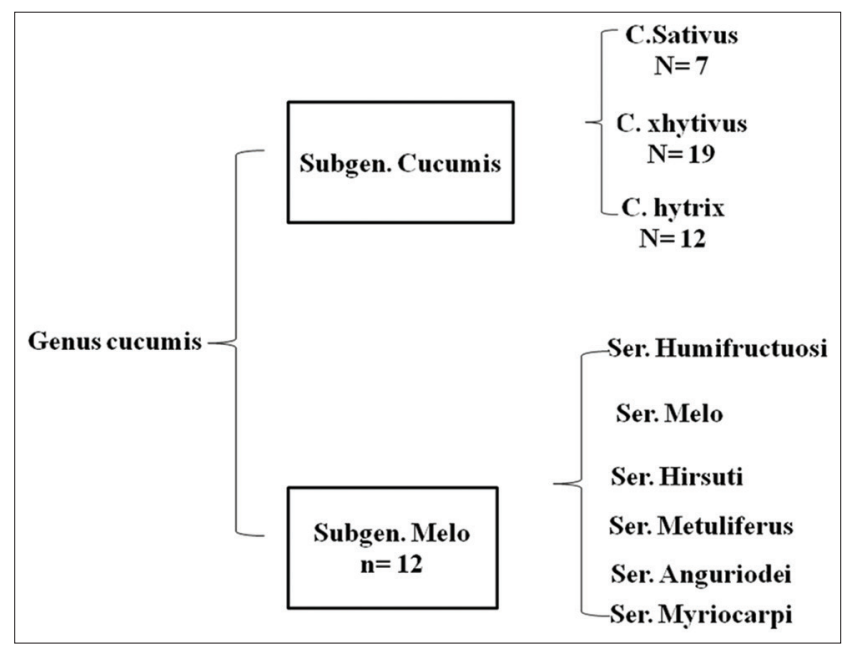

Fig. 1: Classification of Cucumis genus cucumber sap but also provide the scientific basis for the wide use of cucumber in cosmetic industry and as well as in traditional medicine as a skin conditioner [11]. Long-term use of non-steroidal anti-inflammatory drugs (NSAIDs) and Helicobacter pylori bacteria infection are two major factors that can disturb the mucosal lining resistance $[12,13]$.

Aspirin causes mucosal damage by interfering with prostaglandin synthesis, increasing the secretion of acid and back diffusion of $\mathrm{H}+$ ion [14-17]. Overall, the extract of ethanolic $400 \mathrm{mg} / \mathrm{kg}$ body weight has exposed a substantial and major protection in opposition to gastric ulcers in all the models. The ulcer protective activity of cucumber may be backed by occurrence of alkaloids, flavonoid, polyphenols, and steroids [18-20] have been verified reduction of free acidity, total acidity, gastric acid volume, antioxidant, immunimodulatory activity, and anti-inflammatory $[21,22]$. These phytoconstituents of $C$. sativus may have additional contributed to the reduction of peptic ulcer. However, further studies require to be approved out to isolate the desire bioactive phytoconstituents, and underline the full evidence of method of action of $C$. sativus not in support of gastric ulcer.

\section{ANTICANCER ACTIVITY}

Cucurbitacins are extremely oxygenated tetracyclic-triterpenes, primarily establish in the Cucurbitaceae family. Cucurbitacin B is a anticancer (oncogenic) agent naturally isolated from the stems of C. melo. In human leukemia cells, the anticancer activity of Cucurbitacin $B$ have been reported. Cucurbitacin B inhibits Raf/MEK/ERK and STAT3 activation pathway in leukemia cell line K562. Cucurbitacin A along with cucurbitacin $\mathrm{E}$ also own major antitumour activity $[23,24]$.

\section{HEPATOPROTECTIVE EFFECTS}

The dried pedicel of $C$. melo L. has been practical to progress hepatic purpose and to increase the process of gluconeogenesis. It has a protective effect in opposition to CCl4 intoxication. It is used to care for acute, toxic and chronic hepatitis, cirrhosis, jaundice in the liver [25].

\section{DIURETIC EFFECTS}

The diuretic effects of $C$. melo L. were experienced in anesthetized dogs. The ether extract of the seeds extensively increased the urinary volume and chloride substance. The mechanism for the raise the chloride substance may be recognized to decrease tubular reabsorption increased and glomerular filtration rate [26].

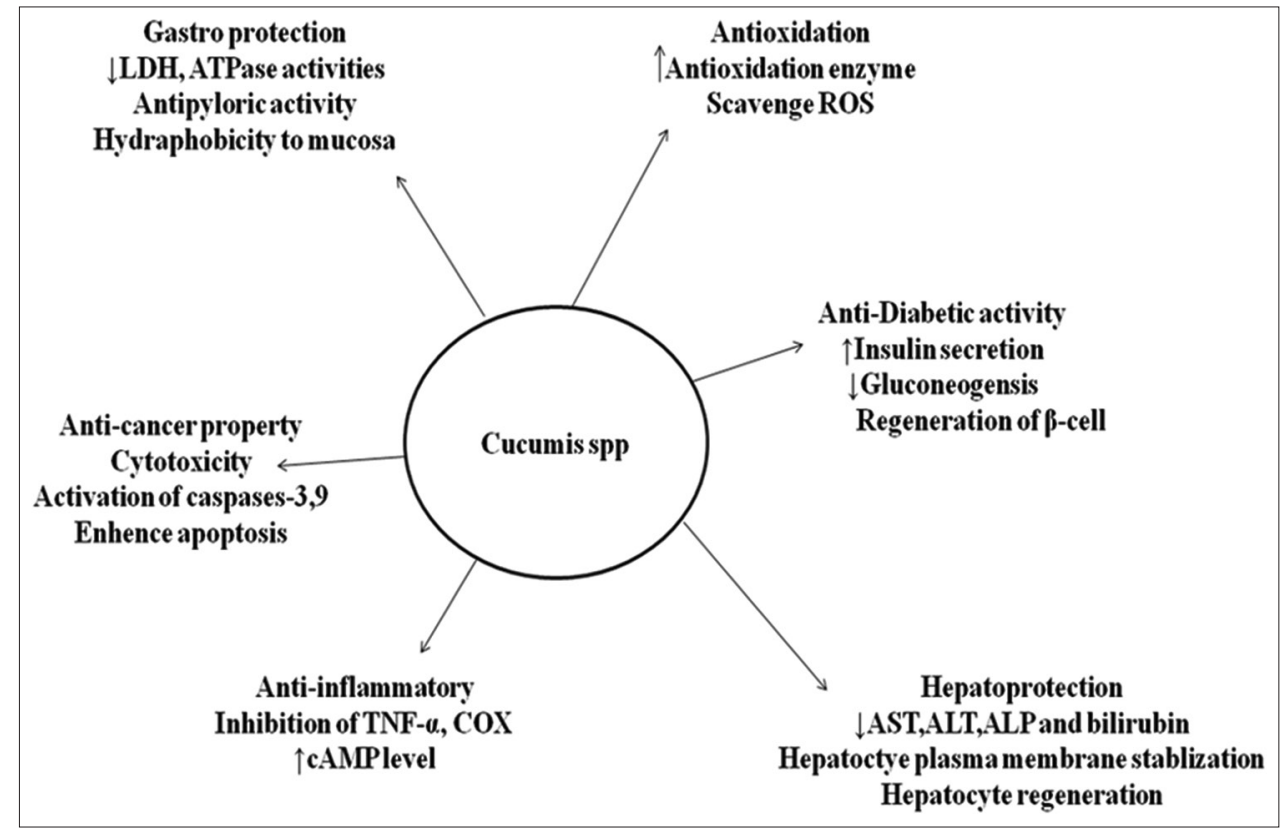

Fig. 2: Pharmacological activity of Cucumis spp 


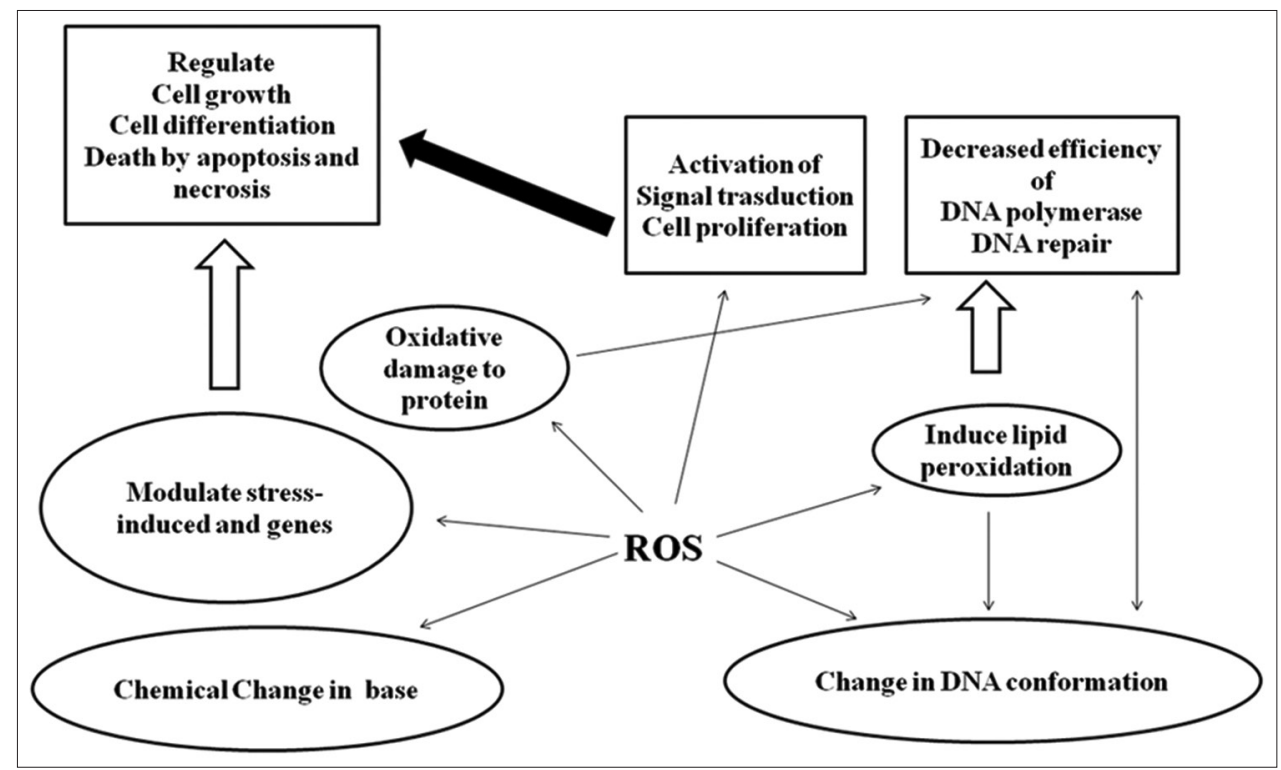

Fig. 3: Antioxidant mechanism and involvement of reactive oxygen species

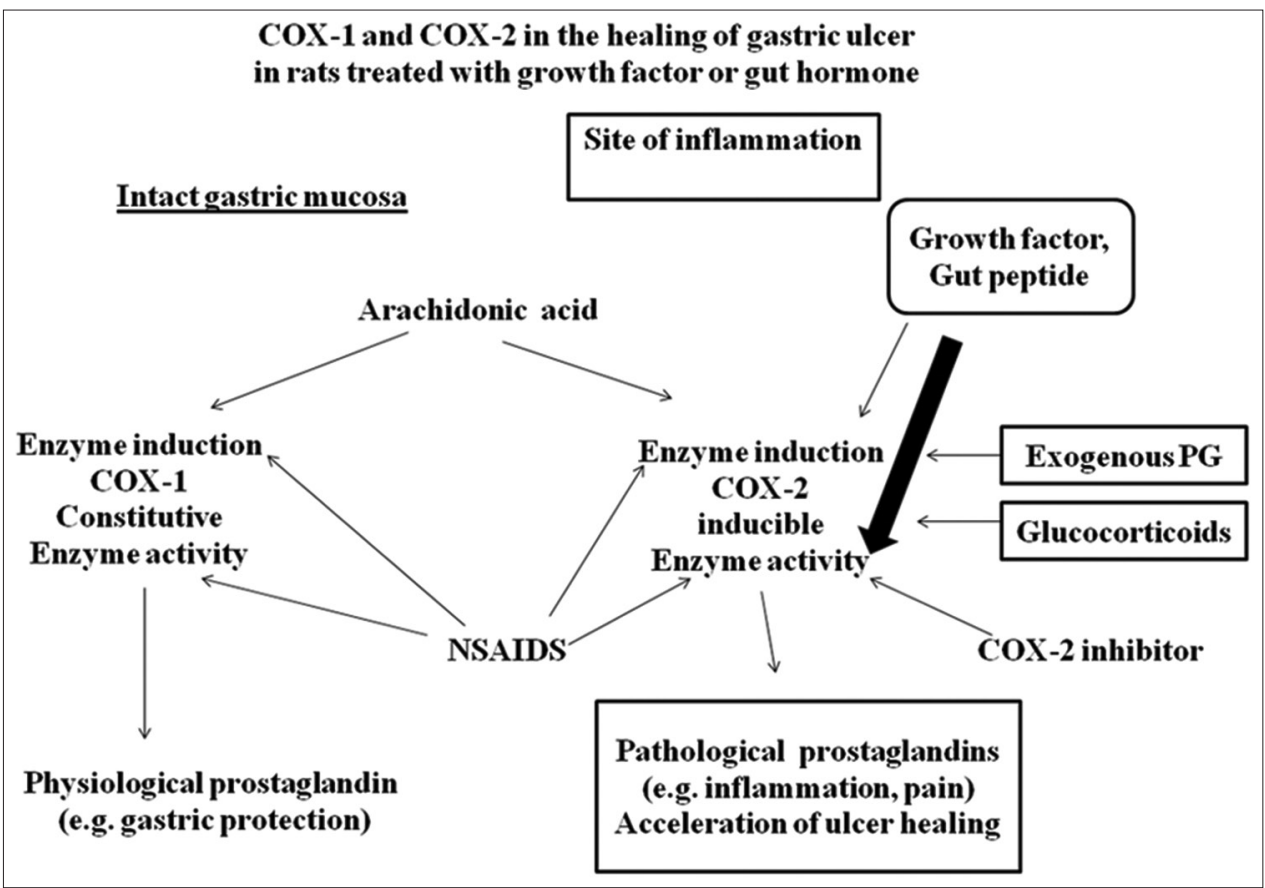

Fig. 4: Antiulcer mechanism and involvement of COX-1, COX-2 and prostaglandin

\section{ANTIHYPOTHYROIDIC EFFECTS}

Administration of fruit peel extracts ( $C$. melo, Mangifera indica, and Citrullus vulgaris) of three tests considerably increased both the thyroid hormones (T3 and T4) with a related diminish in tissue lipid peroxidation, and antiperoxidative role, signifying their thyroid stimulatory. Due to this thyroid stimulatory nature was also showed that in propylthiouracil induces hypothyroid animals [27].

\section{ANTIDIABETIC ACTIVITY}

The fruit peel of extracts of C. melo inverted the CCT-diet (supplemented along with 0.5\% 2-thiouracil, 4\% cholesterol, and 1\% cholic acid) induced raise in the levels of creatine kinase-MB, glucose, tissue lipid peroxidation, and serum lipids. Furthermore, Musk melon improved the levels of insulin and thyroid hormones indicative of their prospective to ameliorate of the plant extract diet induced alterations in thyroid dysfunctions, serum lipids, and hyperglycemia or diabetes mellitus. These favorable effects could be depended on the wealthy content of ascorbic acid and polyphenols in the peel extracts [28]. Oxykine is the cantaloupe melon extract rich content in vegetal superoxide dismutase (SOD) enclosed by polymeric coated film of wheat matrix of gliadin. The treatment of oxykine ameliorated succession and increase of rate of diabetic nephropathy in diabetic Type- 2 rodents. The oxykine deduced renal mesangial cell injury and the diabetes-induced oxidative stress. Oxykine may be a novel loom for the avoidance of diabetes nephropathy [29].

\section{CARDIOVASCULAR EFFECTS}

The chronic utilization of Musk melon juice helps in avoidance of liver steatosis and atherosclerosis [30]. Adenosine separated from an aqueous melon extract inhibited or abolished platelet aggregation 
induced by epinephrine in human, sodium arachidonate, thrombin, ADP, collagen, prostaglandin endoperoxide analog PAF-acether, and $\mathrm{U}-46619$ [31]. The management of cardiovascular diseases is needful by the activity of Musk melon.

\section{ANTHELMINTIC ACTIVITY AND ANTIMICROBIAL ACTIVITY}

The methanolic extracts and n-hexane of the seeds of $C$. melo $\mathrm{L}$. have exposed excellent anthelmintic activity and antimicrobial [32]. C. melo is also useful in the vermifuge [33].

\section{ANTIFERTILITY ACTIVITY}

C. melo is favorites plant of Bhat community intended for the management or regulating fertility [34].

\section{IMMUNO-MODULATORY EFFECT}

The combination of SOD rich wheat gliadin and $C$. melon extract increased in particular the invention of type 1 helper T lymphocytes (Th1) along with the expression of IL- 4 and INF- ${ }^{\gamma}$. However, the construction of IgE (allergic production) remained trivial, and the construction of IgA did not modify thereby reinforcing the suggestion of the immunomodulatory action of wheat Glisodin. That action might outcome from the activation of antigen presenting cells by the gliadin-SOD arrangement. This establishment induces the release of $\mathrm{H}_{2} \mathrm{O}_{2}$ and nitric oxide (NO), which in twist activates Gpx and catalase, followed by the expression of IL- 4 and INF- ${ }^{\gamma}$ cytokines. The immune response is increased by the activated of antigen presenting cell toward a type 1 helper T lymphocytes response [35].

\section{TRADITIONAL USES OF GENUS-CUCUMIS}

Traditionally, the genus Cucumis plants were used in the treatment of many diseases which reported in the literature [36-39].

The Cucumis plant show purgative, dyspepsia, useful in menorrhagia, Musk melon seeds are helpful in dysuria and painful discharges, facilitate in maintaining kidney functions, the Kernels are prescribed for stomach cancer, roots (single piece in $60 \mathrm{~g}$ of lime water) are valuable emetic agents, possess antigout properties, and antirheumatic. The fruit can be used as a cleansing agent or moisturizer, cooling agent for the skin, prevent cardiac dysfunction, and reduce blood pressure, fruit pulp is engaged as a lotion for acute and chronic eczema and peduncles are used to deal with indigestion and anasarca.

\section{CONCLUSION}

A lot of research has been established that Cucumis species product exhibits multiple biological activities. Czech collections of Cucumis spp. genetic possessions include 895 accessions of cultivated C. melo and $C$. sativus species and wild species of 89 accessions. Musk melon is attractive luscious tasty and tasty household produce consumed for its medicinal, and nutritive properties. Pharmacological experiment conducted on C. melo and some Cucumis spp., point to its immense prospective in the management of conditions such as inflammation, pain, cancer, cough, liver diseases, and cardiovascular disorders. The wide use of cucumber in cosmetic industry and as well as in traditional medicine as a skin conditioner. Musk melon shows excellent antiulcer and antioxidant potential. Those plants have incredible recognition now and hold surprising promise for the future. In view of the low toxicity of Musk melon plant that included many parts and their employ as a nutraceutical as well as a clinical studies also, reliable medicine need to be carried out only to cement $C$. melo and their spp. As a significant constituent of our biodiversity, in view of the fact that there are no any side effects have been reported till now, Musk melon may be look upon as a distinctive affordable, tasty, and safe fruit medicine.

\section{REFERENCES}

1. Schaefer H, Renner SS. Phylogenetic relationships in the order Cucurbitales and a new classification of the gourd family (Cucurbitaceae). Taxon 2011;60(1):122-38.
2. Anjum P, Qaiser M. Pollen flora of Pakistan. Cucurbitaceae. Pak J Bot 2008;40(1):9-16.

3. Gill NS, Sharma G. Cucumis trigonus Roxb: A review. International journal of recent advances in pharmaceutical research 2015;5(1):45-50.

4. Kirkbride JH. Biosystematic Monograph of the Genus Cucumis (Cucurbitaceae). Vol. 159. Boone, NC, USA: Parkway Publishers; 1993. p. 24-9.

5. Asif-Ullah M, Kim KS, Yu YG. Purification and characterization of a serine protease from Cucumis trigonus Roxburghi. Phytochemistry 2006;67:870-5.

6. Naveena BM, Mendiratta SK, Anjaneyulu AS. Tenderization of buffalo meat using plant proteases from Cucumis trigonus Roxb (Kachri) and Zingiber officinale roscoe (Ginger rhizome). Meat Sci 2004;68:363-9.

7. Thippeswami BS, Thakker SP. Cardioprotective effect of Cucumis trigonus Roxb. On isoproterenol-induced myocardial infarction in rats. Am J Pharmacol Toxicol 2009;4(2):29-37.

8. Gill NS, Bajwa J, Sharma P, Dhiman K, Sood S, Sharma PD, et al. Evaluation of therapeutic potential of traditionally consumed Cucumis melo seeds. Asian J Plant Sci 2011;10(1):86-91.

9. Ismail HI, Chan KW, Mariod AA, Ismail M. Phenolic content and antioxidant activity of cantaloupe (Cucumis melo) methanolic extracts. Food Chem 2010;119(2):643-7.

10. Gill NS, Bajwa J, Sharma P, Dhiman K, Sood S, Sharma PD, et al. Evaluation of antioxidant and anti-ulcer activity of traditionally consumed Cucumis melo seeds. J Pharmacol Toxicol 2011;6(1):82-9.

11. Manjula B, Swamy YH, Devaraja KS, Kemparaju K. Clot promoting and dissolving properties of cucumber (cucumis sativus) sap, validating its use in traditional medicine. Int J Pharm Pharm Sci 2015;7(1):101-11.

12. Vane JR. Inhibition of prostaglandin synthesis as a mechanism of action of aspirin-like drugs. Nat N Biol 1971;231:232-5.

13. Soll AH, Weinstein WM, Kurata J, McCarthy D. Nonsteroidal anti-inflammatory drugs and peptic ulcer disease. Ann Intern Med 1991;114:307-19.

14. Kauffman G. Aspirin-induced gastric mucosal injury: Lessons learned from animal models. Gastroenterology 1989;96 2 Suppl:606-14.

15. Holt KM, Hollander D. Acute gastric mucosal injury: Pathogenesis and therapy. Annu Rev Med 1986;37:107-24

16. Hawthorne AB, Mahida YR, Cole AT, Hawkey CJ. Aspirin-induced gastric mucosal damage: Prevention by enteric-coating and relation to prostaglandin synthesis. Br J Clin Pharmacol 1991;32(1):77-83.

17. Wallace JL. Prostaglandins, NSAIDs, and gastric mucosal protection: Why doesn't the stomach digest itself? Physiol Rev 2008;88(4):1547-65.

18. de Sousa Falcão H, Leite JA, Barbosa-Filho JM, de AthaydeFilho PF, de Oliveira Chaves MC, Moura MD, et al. Gastric and duodenal antiulcer activity of alkaloids: A review. Molecules 2008;13(12):3198-223.

19. Vinothapooshan G, Sundar K. Anti-ulcer activity of Mimosa pudica leaves against gastric ulcer in rats. Res J Pharm Biol Chem Sci 2010;1(4):606-14

20. Mota KS, Dias GE, Pinto ME, Luiz-Ferreira A, Souza-Brito AR, Hiruma-Lima CA, et al. Flavonoids with gastroprotective activity. Molecules 2009;14(3):979-1012.

21. Gohain N, Prakash A. An ethnobotanical survey of anti-malarial plants in some highly malaria. Int J Pharm Pharm Sci 2015;7(9):147-52.

22. Patel M, Patel P, Patel M. Aqueous extract of Ficus bengalensis Linn. Bark for inflammatory bowel disease. J Young Pharm 2010;2(2):130-6.

23. Chan KT, Li K, Liu SL, Chu KH, Toh M, Xie WD. Cucurbitacin B inhibits STAT3 and the Raf/MEK/ERK pathway in leukemia cell line K562. Cancer Lett 2010;289(1):46-52.

24. Wright CI, Van-Buren L, Kroner CI, Koning MM. Herbal medicines as diuretics: A review of the scientific evidence. J Ethnopharmacol 2007;114(1):1-31.

25. Parmar HS, Kar A. Protective role of Mangifera indica, Cucumis melo and Citrullus vulgaris peel extracts in chemically induced hypothyroidism. Chem Biol Interact 2009;177(3):254-8.

26. Vikasari SN, Sukandar EY, Sutjiatmo AB, Riyanti S. Diuretic effect of the ethanol extracts of Phyllanthus acidus 1 (skeels) leaves in wistar rats. Int J Pharm Pharm Sci 2005;7(1):120-3

27. Naito Y, Akagiri S, Uchiyama K, Kokura S, Yoshida N, Hasegawa G, et al. Reduction of diabetes-induced renal oxidative stress by a cantaloupe melon extract/gliadin biopolymers, oxykine, in mice. Biofactors 2005;23(2):85-95.

28. Décordé K, Ventura E, Lacan D, Ramos J, Cristol JP, Rouanet JM. An SOD rich melon extract Extramel prevents aortic lipids and liver steatosis in diet-induced model of atherosclerosis. Nutr Metab Cardiovasc Dis 2010;20:301-7. 
29. Altman R, Rouvier J, Weisenberger H. Identification of platelet inhibitor present in the melon (Cucurbitacea cucumis melo). Thromb Haemost 1985;53(3):312-3.

30. Ibrahim SR. New 2-(2-phenylethyl)chromone derivatives from the seeds of Cucumis melo L var. reticulatus. Nat Prod Commun 2010;5(3):403-6.

31. Zinchenko TV, Mindlin MZ, Prokopovich NN. Anthelmintic properties of Cucumis melo seeds. Farmakol Toksikol 1955;18(5):41-3.

32. Lal D, Lata K. Plants used by the Bhat community for regulating fertility. Econ Bot 1980;34(3):273-5

33. Debnath B, Uddin J, Patari P, Das M, Maiti D, Manna K. Estimation of alkaloids and phenolics of five edible cucurbitaceous plants and their antibacterial activity. Int J Pharm Pharm Sci 2015;7(12):223-7.

34. Gopalkrishnan SB, Kolaiarasi T. Comparative phytochemical screening of the fruits of Cucumis trigonus Roxb. and Cucumis sativus linn. World J Pharm Pharm Sci 2014;3:1455-68.

35. Bar-Nun N, Mayer AM. Cucurbitacin-repressor of induction of laccase formation. Phytochemistry 1989;28:1369-71.

36. Okwuosa CN, Okoi ER, Achukwu PU, Onuba AC, Azubuike NC. Gastro-protective effect of crude hexane leaf extract of Sesamum indicum in Rabbits. Nig J Physiol Sci 2011;26:49-54.

37. Tripathi KD. Gastrointestinal drugs. Essentials of Medical Pharmacology. $6^{\text {th }}$ ed. New Delhi, India: Jaypee; 2009. p. 627-38.

38. Jamal A, Siddiqui A, et al. A review on gastric ulcer remedies used in Unani system of medicine. Natural product radiance 2006;5(3):153-159.

39. Paris HS, Daunay MC, Janick J. Occidental diffusion of cucumber (Cucumis sativus) 500-1300 CE: Two routes to Europe. Ann Bot 2011;109(1):1-10. 